\title{
Isolation And Identification Of Some Chemical Constituents In Two Different Types Of Fresh Water Macro Algae In Bestansur Village In Suleiman City Kurdistan Region (North Iraq) By Hplc Technique
}

\author{
Trifa Attar Omer \\ Department of Chemistry, School of science, Faculty of science \& science education, University of Suleiman.
}

\begin{abstract}
In the present work HPLC analysis for two genus of green algae were collected locally and identified from Bestansur village fresh water in Sulaimani city in north Iraq in October 2011, shows that contain different alkaloid components such as Chara sp. Contain (Kaemfertin $57.0831 \mu \mathrm{gm} / \mathrm{ml}$, isoquinoline $74.8601 \mu \mathrm{gm} / \mathrm{ml}$ ,corilagin 109.3617 $\mathrm{gm} / \mathrm{ml}$ and colocynthitin $57.3929 \mu \mathrm{gm} / \mathrm{ml}$ ) while Spirogyra contain (Gallic acid 77.2055 $\mu \mathrm{gm} / \mathrm{ml}$,Kaempfertin $67.8407 \mu \mathrm{gm} / \mathrm{ml}$, isoquinoline $69.6164 \mu \mathrm{gm} / \mathrm{ml}$, corilagin $105.8581 \mu \mathrm{gm} / \mathrm{ml}$ and colocynthitin $85.9098 \mu \mathrm{gm} / \mathrm{ml}$ ).

Divert compounds of steroids composition were also analyzed by HPLC technique in two types of macro algae five steroid compounds were detected (stigmasterol $69.9213 \mu \mathrm{gm} / \mathrm{ml}, 73.102 \mu \mathrm{gm} / \mathrm{ml}$, campsterol $98.8401 \mu \mathrm{gm} / \mathrm{ml}, 157.8413 \mu \mathrm{gm} / \mathrm{ml}, \beta$-sitosterol $127.8065 \mu \mathrm{gm} / \mathrm{ml}, 37.1229 \mu \mathrm{gm} / \mathrm{ml}$, avenasterol $43.15194 \mu \mathrm{gm} / \mathrm{ml}, 72.400 \mu \mathrm{gm} / \mathrm{ml}$ and clerosterol $89.6958 \mu \mathrm{gm} / \mathrm{ml}, 84.50799 \mu \mathrm{gm} / \mathrm{ml}$ respectively).

In this study HPLC analysis for Chara show that contain( $\alpha$-tocopherol $334.53417 \mu \mathrm{gm} / \mathrm{ml}, \beta$ tocopherol $175.13087 \mu \mathrm{gm} / \mathrm{ml}$ and $\gamma$-tocopherol $71.7641 \mu \mathrm{gm} / \mathrm{ml}$ ).

In the end of this study ICP analysis for two genus macroalgae shows that contain this element s (Mn,V,Se, $\mathrm{Ca}, \mathrm{Mg}, \mathrm{Cr}, \mathrm{As}, \mathrm{Pb}, \mathrm{Co}, \mathrm{Cd}$ and $\mathrm{Ni}$ ).
\end{abstract}

Key Words: HPLC analysis, macro algae ,Alkaloid, steroid, tocopherol

\section{Introduction}

Macro algae are major contributors to the total marine plant biomass (1).Currently, Macro algae are attracting increasing interest, in view of their low caloric content and high vitamin ,mineral and dietary fiber contents (2), making them attractive to both consumers and the food industry (3).Numerous biological amines and halogenated cyclic nitrogen -containing substances are included in the term alkaloid. The latter is specific from marine organisms and marine algae. They could not be found in terrestrial plants after the isolation of alkaloids; pure active compounds were used in therapy instead of plant extracts. Isolation of active compounds from plants begin in $18^{\text {th }}$ century .Morphine was the first alkaloid extracted from a terrestrial plant in 1805 as reported by Keppel mayer (4) and hordenine was the first alkaloid isolated from a marine algae in 1969.(5,6).

As a consequence of an increasing demand for biodiversity in the screening programs seeking therapeutic drugs from natural products, there is now a greater interest in marine organisms, especially algae.( 7)Sterols are an important family of lipids, present in the majority of the cells .because of different routes of synthesis ,sterols from plants, fungi and animals show marked differences.

Tasende (2000) confirmed that fatty acids and sterol of algal class, families and sometimes even species are characteristics to those particular taxa and could be useful as chemotaxonomic (8).Clinical studies have demonstrated that dietary intake of plant sterols ( as part of the normal diet ,or as a supplement ) may help reduce blood cholesterol level.(9)Vitamin $\mathrm{E}$ is a generic term applied to the tocopherols and tocotrienols (which show similar nutritional properties to $\alpha$-tocopherol (10), these substances are highly stable to heat and acids , and unstable to alkalis ,UV light and oxygen ;in addition ,they are regarded on contact with rancid fats, lead and iron (11). $\alpha$-tocopherol is a liposoluble compounds that is capable of fixing free radicals via its phenol group and is thus considered to play an antioxidant role in biological membranes, lipoproteins and fat deposits, controlling or reducing lipid peroxidation .

In addition, it has been suggested that it helps protect against cancer induced by free -radical generating contaminants, such as ozone or nitrogen dioxide (12). 


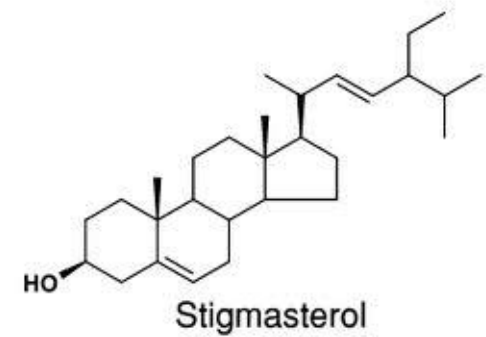

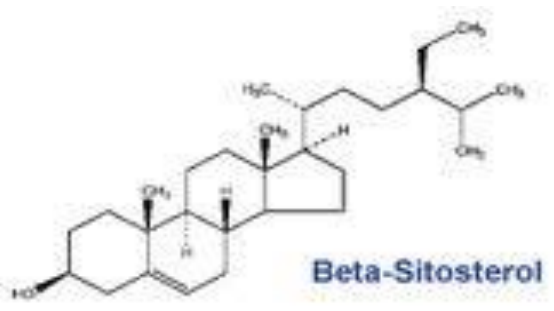

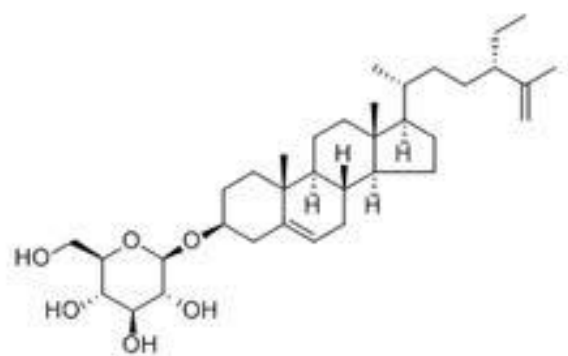

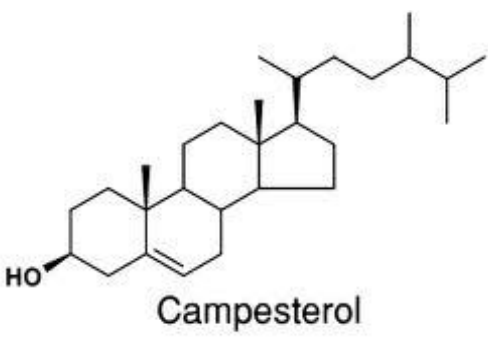

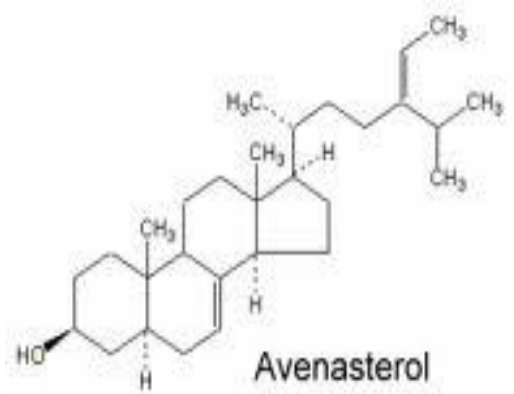

Clerosterol

Fig: (1) Structure of Steroid compounds<smiles>CC(C)(O)C(O)C#N</smiles><smiles>c1ccc2cnccc2c1</smiles>

Isoquinoline

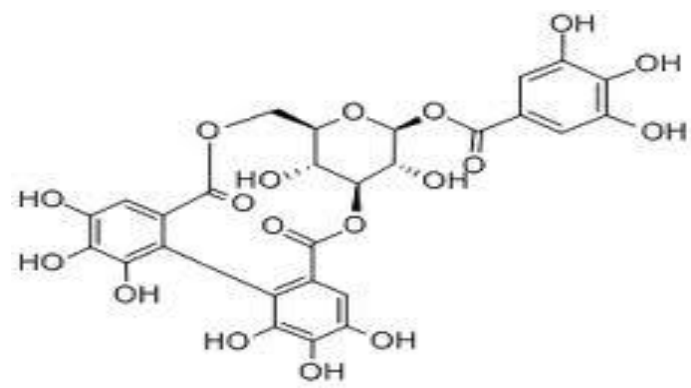

corilagin

Figure :(2) structure of alkaloids compound 
<smiles>[Z][Te]c1c(C)c(O)c(C)c2c1OC(C)(CCCC(C)CCCC(C)CCCC(C)C)CC2</smiles>

Fig: (3) tocopherol structure

\section{Experimental}

Two types of Macro algae (chara sp. ,spirogyra) were collected locally and identified from fresh water in Bestansur village in Sulaimani city in Kurdistan region-north Iraq in October 2011.Algae samples were cleaned at epiphytes and necrotic parts were removed .

Samples were rinsed with sterile water to remove any associated debris .samples was kept under sunshade for 7 days .after drying the samples , it was ground thoroughly to powder form .

After a morphological and chemical characterization, the samples were prepared for determination of different compounds of alkaloids, steroids and tocopherol and ICP -analysis.

\section{A / RP- HPLC determination of alkaloids in chara sp. \& spirogyra. Extraction procedure for alkaloids compound.}

The alcoholic extract of alkaloids were separated on FLC (Fast liquid chromatographic) column, 3um particle size $(50 \times 4.6 \mathrm{~mm} \mathrm{I.D)}$ chiral coloumn,mobile phase were $0.01 \mathrm{M}$ phosphate buffer PH 8.2: acetonitrile $(60: 40 \mathrm{v} / \mathrm{v})$ detection UV set as $220 \mathrm{~nm}$, Flow rate $0.9 \mathrm{ml} / \mathrm{min}$, the sequence of the eluted material of the standard were as follow, each standard was $25 \mu \mathrm{g} / \mathrm{ml}$.

Assay results for calibration standards was of the linear range of $1-100 \mu \mathrm{g} / \mathrm{ml}$, the recovery rate of $\% 96.8, \mathrm{RSD}$ of $\% 1.8(\mathrm{n}=5)$

The separation occurred on liquid -chromatography shimadzu 2010 LC equipped with binary delivery pump model 2010 shmadzu, the eluted peaks were monitored by UV-VIS 2010 SPD spectrophotometer.

\section{Preparation of sample}

$1 \mathrm{gm}$ of the sample added in $250 \mathrm{ml}$ glass beaker $250 \mathrm{ml}$ of $0.25 \%$ acetic acid in ethanol has been added the beaker was covered with glass watch for $4 \mathrm{hrs}$, the extract where filtered and concentrated to $100 \mathrm{ml}$ using rotary evaporator drop of $\% 5$ ammonium hydroxide were added to precipitation the alkaloids, the precipitated were filtered and dissolve in $1 \mathrm{ml}$ of mobile phase ,then separated on HPLC under the same condition of standard. Concentration for each sample were quantitatively determined by comparison the peak area of the standard with that of the samples.

\section{B / Extraction procedure for steroid compounds. Active ingredient sterols:}

The extract were separated on FLC (Fast liquid chromatography, columns, C-18,3 $\mu \mathrm{m}$ particle size ( $50 \times 4.6 \mathrm{~mm} \mathrm{ID)}$, mobile phase $0.1 \%$ acetic acid in deionized water (solvent A) and acetonitrile (solvent B) using linear gradient from 0-100\% B in 10 minutes, detection UV set as $275 \mathrm{~nm}$, flow rate $1.2 \mathrm{ml} / \mathrm{min}$ temperature $30 \mathrm{c}$. The separation occurred on liquid - chromatography shimadzu 2010 LC equipped with binary pump model 2010 shimadzu the eluted peaks were monitored by UV-VIS 2010 SPD spectrophotometer.

\section{Extraction procedure:}

$1 \mathrm{gm}$ sample has been dissolved in $5 \mathrm{ml}$ of hot water for 2 hour, then using Ultrasonic bath for 20 minutes to get all extract dissolved in hot water $60 \mathrm{c}$ degree, then the extract were filtered on filter paper no $1,0.5 \mathrm{~mm}$ to separate the fiber , $20 \mu \mathrm{gm}$ from the sample injected on HPLC system .

The sequences of the eluted material of the standard were as follow, each standard was $25 \mu \mathrm{g} / \mathrm{ml}$.

\section{C/ RP- HPLC determination of tocopherol}

Fast soluble tocopherols were separated on FLC (Fast liquid chromatographic ) column ,discovering HSC $-18,3 \mu \mathrm{gm}$ particle size $(50 \times 4.6 \mathrm{~nm}$ I.D) column, Mobile phase : acetonitrile, detection :UV set at 290 $\mathrm{nm}$,Flow rate $1.0 \mathrm{ml} / \mathrm{min}$,injection $: 20 \mu \mathrm{L}$.the sequence of the eluted standard was $50 \mu \mathrm{g} / \mathrm{ml}$. 


\section{D / Determination of elements :}

The sample $1 \mathrm{gm}$. weighed and adds 2 drops of nitric acid conc. And the volume was completed to 50 $\mathrm{ml}$ distilled water the solution was injected to OES - ICP Perkin Elmer 2100 for determine.

\section{Calculation}

Concentration of sample $\mu \mathrm{g} / \mathrm{ml}=$ area of sample/area of standard $\times$ conc. of standard $\times$ dilution factor

\section{Result and discussion:}

HPLC analysis of alkaloid compounds in two green genus Macro algae ( chara and spirogyra) are represented in table (1-2), from the result chara sp. Contain four types of alkaloids like (Kaempfertin , isoquinoline ,corilagin and colocynthitin), While spirogyra contain five types of alkaloid compounds (Gallic acid ,Kaempfertin ,isoquinoline, corilagin and colocynthitin) ,HPLC Chromatogram's of two types of macro algae for alkaloids show in fig (4),(5) and (6)

The structure of some alkaloids compound shown in Fig -1-

Two green genus Macro algae contain (Kaempfertin, isoquinoline, corilagin and colocynthitin) while chara sp. not contain Gallic acid.

Also HPLC analysis of steroid compounds in two green genus macro algae (chara sp. and spirogyra) are represented in table (3-4), from the result chara and spirogyra contain five types of steroid compounds like (stigmasterol , campesterol , $\beta$-sito sterol , avenasterol and clerosterol ) from the result appear that chara contain high amount of $\beta$-sitosterol $127.80656 \mu \mathrm{gm} / \mathrm{ml}$ while spirogyra contain high amount of campesterol.,in Fig -2show structure of all steroids compound,HPLC Chromatogram's of two types of macro algae for steroids show in fig (7), (8) and (9) HPLC analysis for tocopherol in chara sp.are represented in table (5) show that contain $\alpha$ tocopherol $334.530417 \mu \mathrm{gm} / \mathrm{ml}, \beta$-tocopherol $175.13087 \mu \mathrm{gm} / \mathrm{ml}$ and $\gamma$ - tocopherol $71.764118 \mu \mathrm{gm} / \mathrm{ml}$ .from the result appear that contain high amount of $\alpha$-tocopherol $334.530417 \mu \mathrm{gm} / \mathrm{ml}$ in Fig -3- show the chemical structure of $\alpha$ - tocopherol and low amount of $\gamma$ - tocopherol $71.764118 \mu \mathrm{gm} / \mathrm{ml}$.HPLC Chromatogram's of two types of macro algae for tocotocopherol show in fig (10), (11)

In the end Elemental analysis have been done by Inductive couple plasma (ICP) technique (OES - ICP Perkin Elmer 2100) for each types of Macro algae and the result cited in table (6). from the result show that contain (Mn , V, Se , $\mathrm{Ca}, \mathrm{Mg}, \mathrm{Cr}, \mathrm{As}, \mathrm{Pb}, \mathrm{Co}, \mathrm{Cd}, \mathrm{Ni})$ from the results appear that contain high amount of $\mathrm{Ca}$ , $\mathrm{Mg}$. And (Co) does not contain in spirogyra sp.

Table -1- Alkaloid compounds in chara sp

\begin{tabular}{|c|c|c|c|c|c|c|c|}
\hline no & subjects & Rt/minute & area/standard & df & area/sample & conce. $\mu \mathrm{g} / \mathrm{ml}$ & $\begin{array}{c}\text { conce. of } \\
\text { sample }\end{array}$ \\
\hline 1 & Gallic acid & 1.17 & 29925 & 3 & & & 0.0000 \\
\hline 2 & Kaempfertin & 2.19 & 40060 & 3 & 30490 & 25 & 57.0831 \\
\hline 3 & isoquinoline & 3.11 & 45597 & 3 & 45512 & 25 & 74.8602 \\
\hline 4 & corilagin & 4.3 & 28021 & 3 & 40859 & 25 & 109.3617 \\
\hline 5 & colocynthitin & 5.19 & 49689 & 3 & 38024 & 25 & 57.3930 \\
\hline
\end{tabular}

Table (2): alkaloid compounds in spirogyra

\begin{tabular}{|c|c|c|c|c|c|c|c|}
\hline no & subjects & Rt/minute & area/standard & df & area/sample & conce. $\mu \mathrm{g} / \mathrm{ml}$ & $\begin{array}{c}\text { conce. of } \\
\text { sample }\end{array}$ \\
\hline 1 & Gallic acid & 1.17 & 29925 & 3 & 30805 & 25 & 77.2055 \\
\hline 2 & Kaempfertin & 2.19 & 40060 & 3 & 36236 & 25 & 67.8407 \\
\hline 3 & isoquinoline & 3.11 & 45597 & 3 & 42324 & 25 & 69.6164 \\
\hline 4 & corilagin & 4.3 & 28021 & 3 & 39550 & 25 & 105.8581 \\
\hline 5 & colocynthitin & 5.19 & 49689 & 3 & 56917 & 25 & 85.9099 \\
\hline
\end{tabular}


Table (3): steroid compounds in char a sp.

\begin{tabular}{|c|c|c|c|c|c|c|c|}
\hline no & subjects & Rt/minute & area/standard & df & area/sample & conce. $\mu \mathrm{g} / \mathrm{ml}$ & $\begin{array}{c}\text { conce. of } \\
\text { sample }\end{array}$ \\
\hline 1 & stigmasterol & 0.99 & 21221 & 3 & 19784 & 25 & 69.9213 \\
\hline 2 & campesterol & 2.15 & 21597 & 3 & 28462 & 25 & 98.8401 \\
\hline 3 & $\beta$-sitosterol & 3 & 22973 & 3 & 39148 & 25 & 127.8066 \\
\hline 4 & avenasterol & 3.92 & 24496 & 3 & 14094 & 25 & 43.1519 \\
\hline 5 & clerosterol & 4.99 & 19878 & 3 & 23773 & 25 & 89.6959 \\
\hline
\end{tabular}

Table (4): steroid compounds in spirogyra

\begin{tabular}{|c|c|c|c|c|c|c|c|}
\hline no & subjects & Rt/minute & area/standard & df & area/sample & conce. $\mu \mathrm{g} / \mathrm{ml}$ & $\begin{array}{c}\text { conce. of } \\
\text { sample }\end{array}$ \\
\hline 1 & stigmasterol & 0.99 & 21221 & 3 & 20684 & 25 & 73.1021 \\
\hline 2 & campesterol & 2.15 & 21597 & 3 & 45452 & 25 & 157.8414 \\
\hline 3 & $\beta$-sitosterol & 3 & 22973 & 3 & 11371 & 25 & 37.1229 \\
\hline 4 & avenasterol & 3.92 & 24496 & 3 & 23647 & 25 & 72.4006 \\
\hline 5 & clerosterol & 4.99 & 19878 & 3 & 22398 & 25 & 84.5080 \\
\hline
\end{tabular}

Table (5): tocopherol compounds in chara $\mathrm{sp}$

\begin{tabular}{|c|c|c|c|c|c|c|c|}
\hline no & subjects & Rt/minute & area/standard & $\mathrm{df}$ & area/sample & conce. $\mu \mathrm{g} / \mathrm{ml}$ & $\begin{array}{c}\text { conce. of } \\
\text { sample }\end{array}$ \\
\hline 1 & $\begin{array}{c}\alpha- \\
\text { tocopherol }\end{array}$ & 2.08 & 18612 & 3 & 41509 & 50 & 334.5342 \\
\hline 2 & $\begin{array}{c}\beta- \\
\text { tocopherol }\end{array}$ & 2.89 & 36869 & 3 & 43046 & 50 & 175.1309 \\
\hline 3 & $\begin{array}{c}\gamma- \\
\text { tocopherol }\end{array}$ & 3.82 & 24012 & 3 & 11488 & 50 & 71.7641 \\
\hline
\end{tabular}

Table 6: ICP determination of elements

\begin{tabular}{|c|c|c|}
\hline Elements & $\begin{array}{c}\text { Conc.in ppm } \\
\text { Chara sp }\end{array}$ & $\begin{array}{c}\text { Conc.in ppm } \\
\text { Spirogyra }\end{array}$ \\
\hline $\mathrm{Mn}$ & 1.744 & 4.578 \\
\hline $\mathrm{V}$ & 0.403 & 0.506 \\
\hline $\mathrm{Se}$ & 0.181 & 0.156 \\
\hline $\mathrm{Ca}$ & 931 & 1673 \\
\hline $\mathrm{Mg}$ & 149 & 106 \\
\hline $\mathrm{Cr}$ & 0.039 & 0.035 \\
\hline $\mathrm{As}$ & 0.271 & 0.209 \\
\hline $\mathrm{Pb}$ & 0.150 & 0.146 \\
\hline $\mathrm{Co}$ & 0.208 & $\mathrm{Nil}$ \\
\hline $\mathrm{Cd}$ & 10.86 & 2.058 \\
\hline $\mathrm{Ni}$ & 2.251 & 0.231 \\
\hline
\end{tabular}




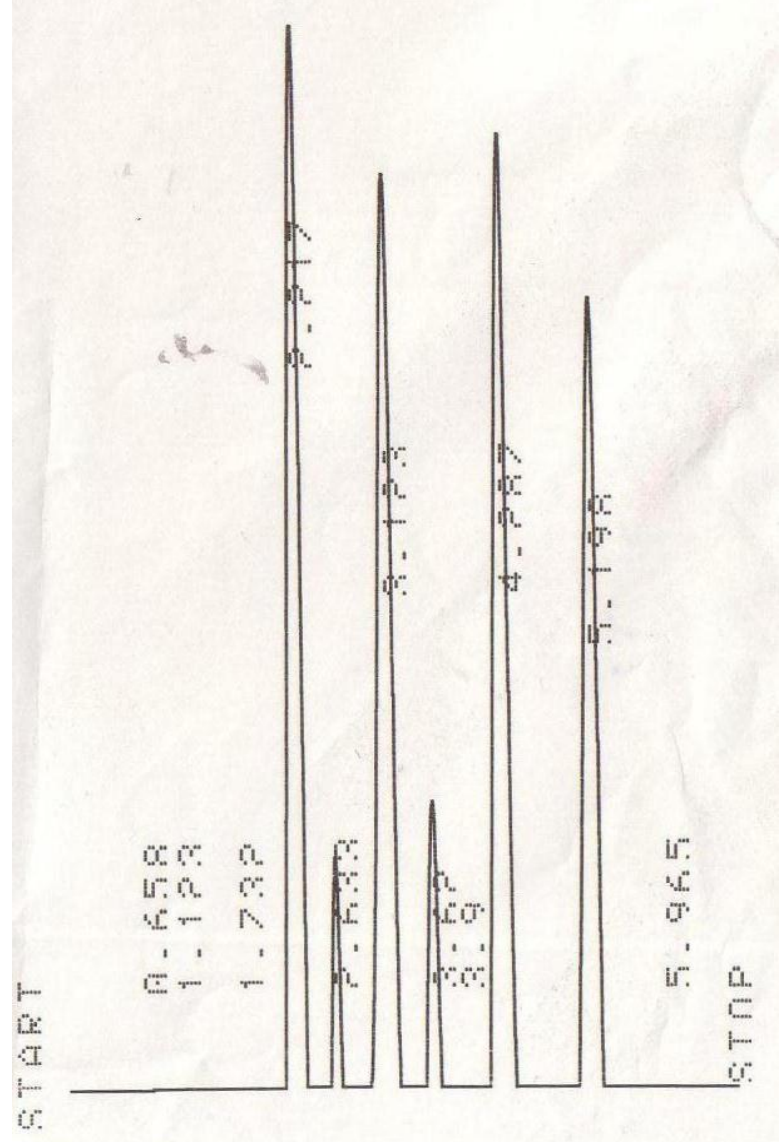

Fig (4): HPLC Chromatograms' of alkaloids compounds in chara sp.

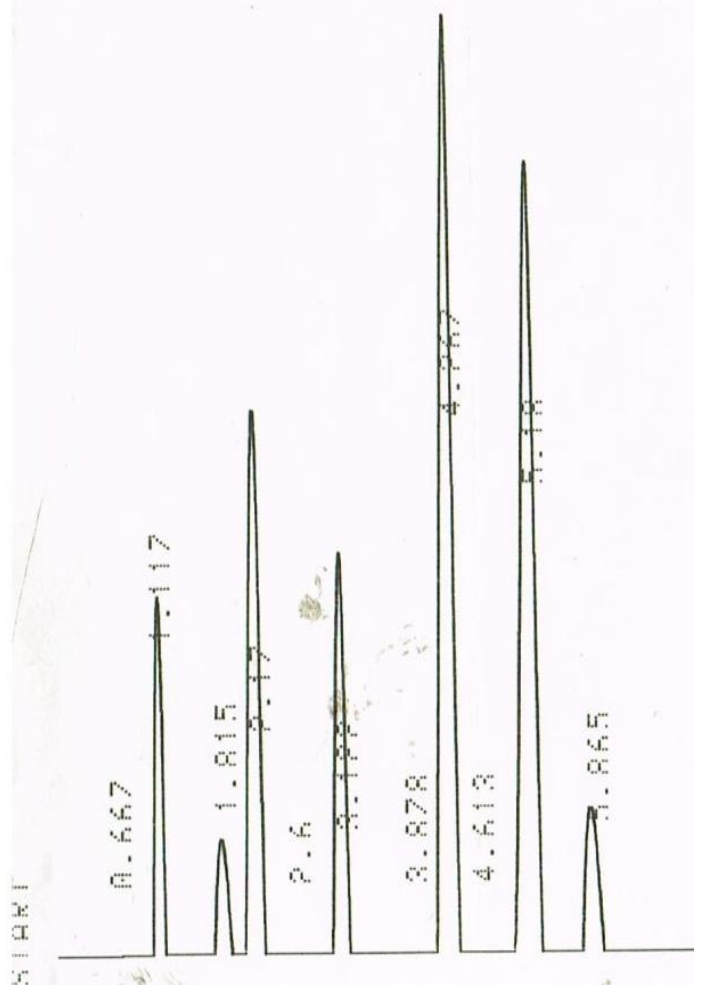

Fig (5): HPLC Chromatograms' of alkaloids compounds in spirogra sp. 


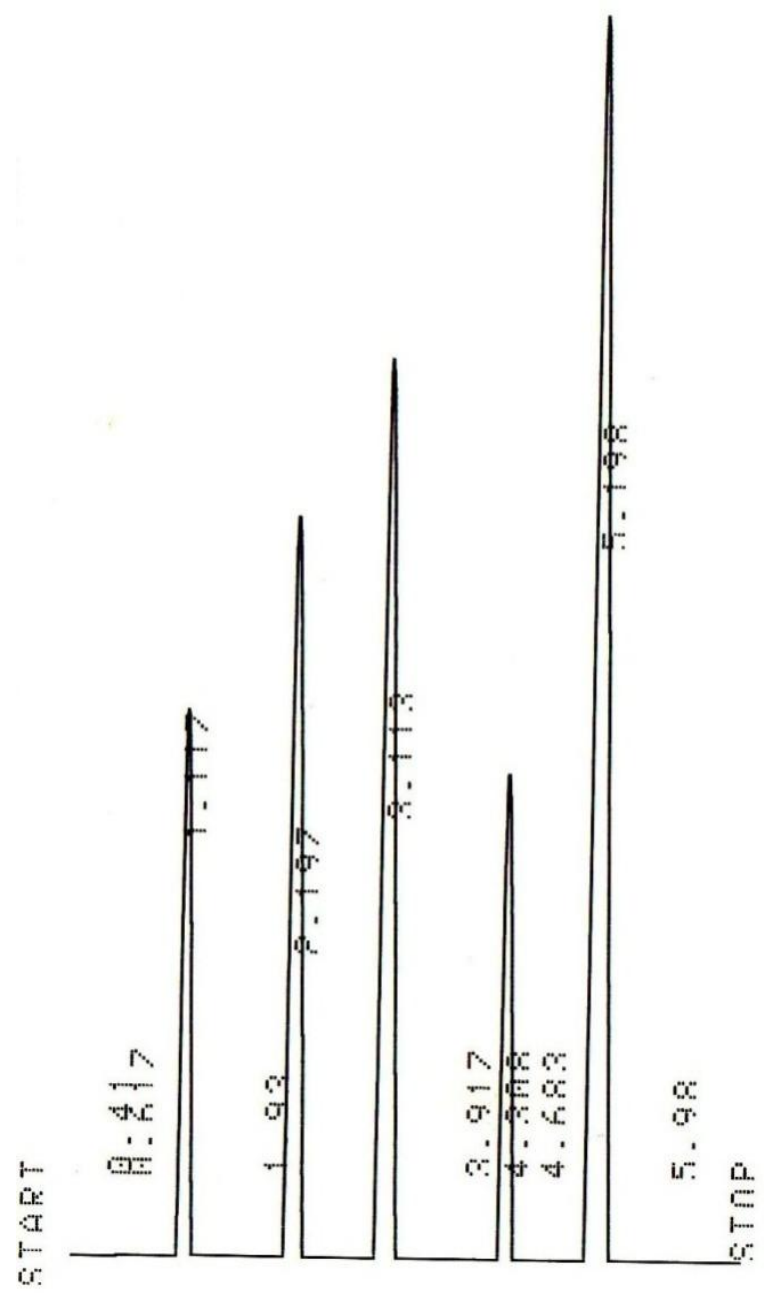

Fig(6): HPLC Chromatograms of a mixture of authentic standards of alkaloids compounds

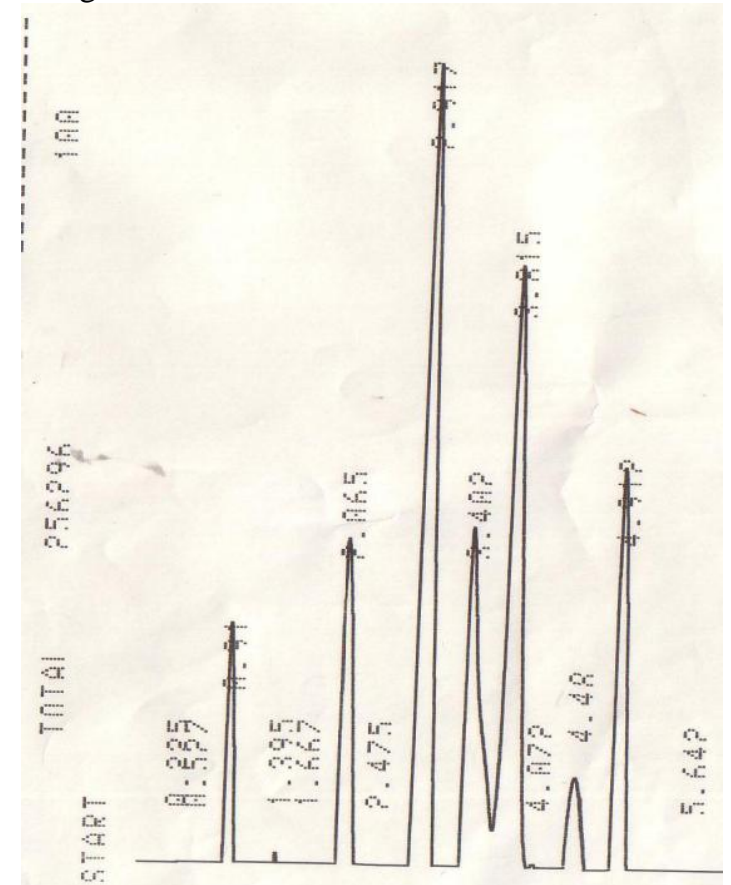

Fig (7): HPLC Chromatograms' of steroids compounds in chara sp. 


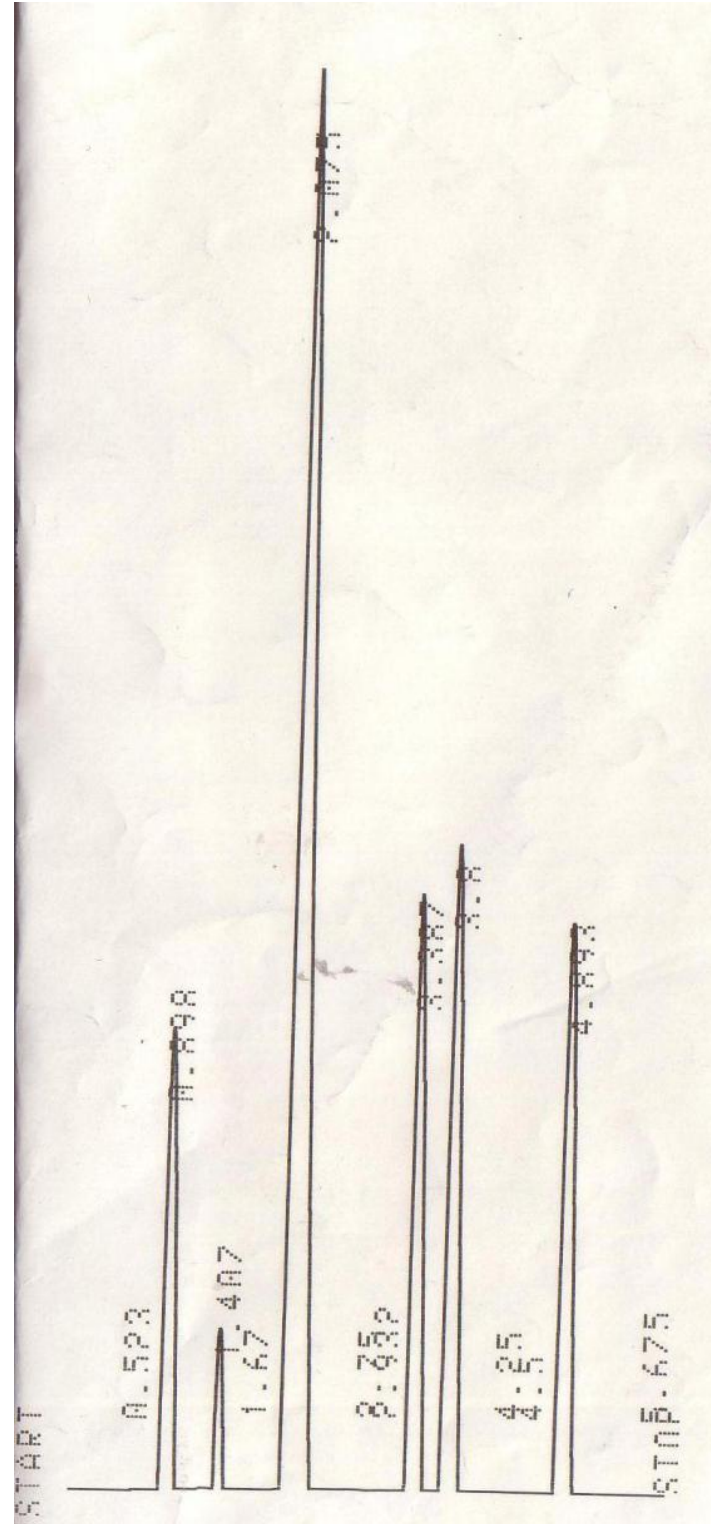

Fig (8): HPLC Chromatograms' of steroids compounds in spirogyra sp.

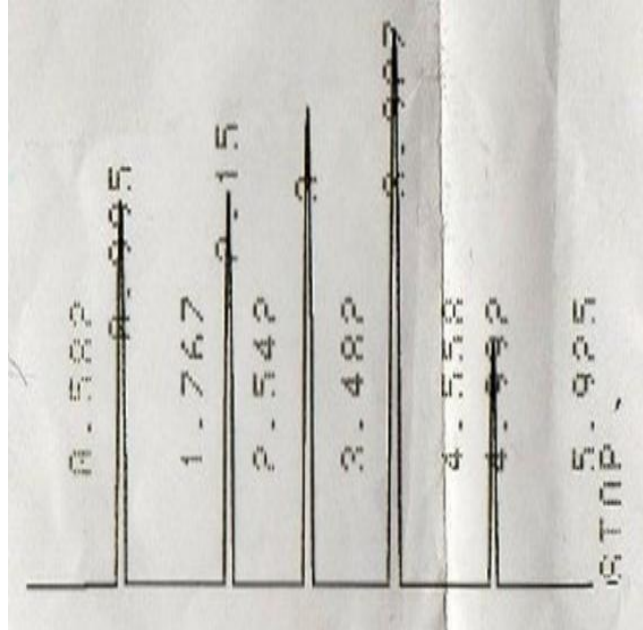

Fig(9): HPLC Chromatogram's of a mixture of authentic standards of steroids compounds 


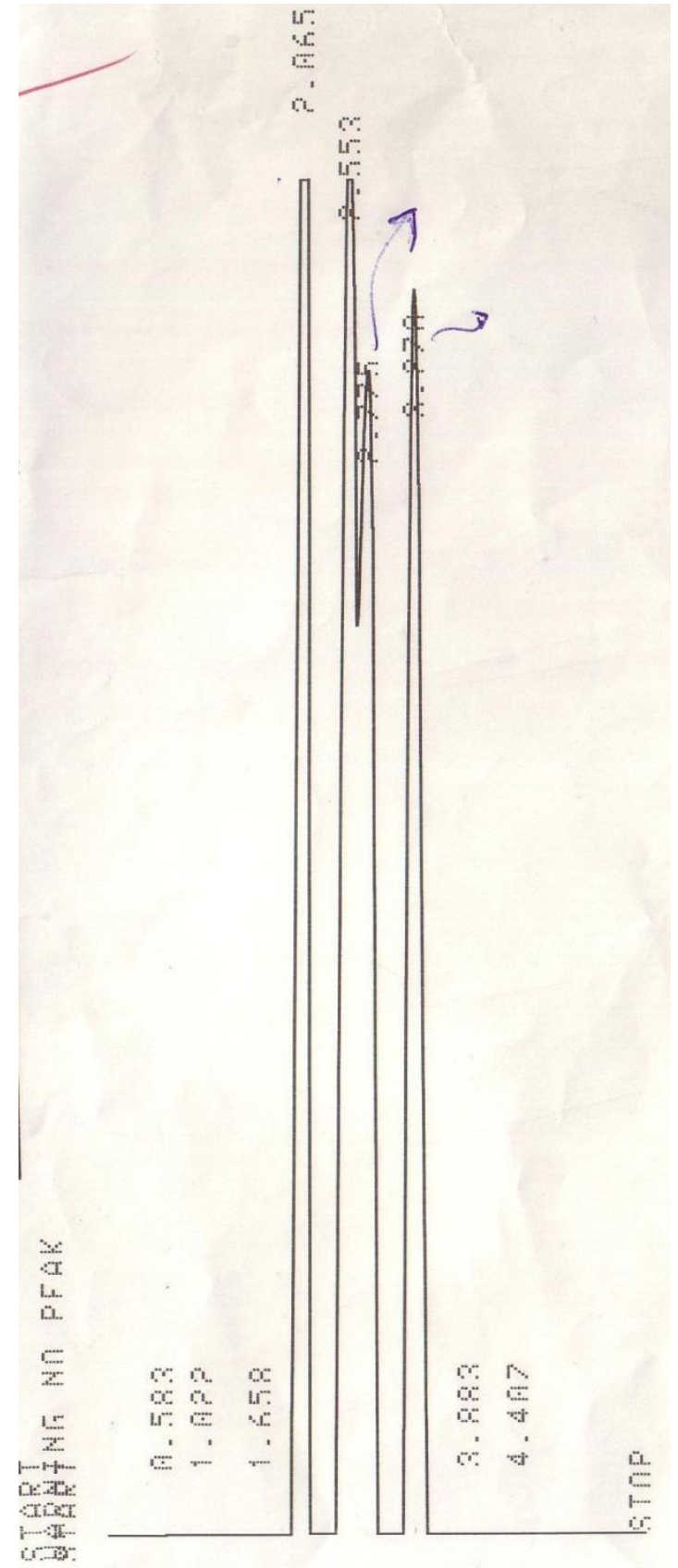

Fig (10):HPLC Chromatograms' of tocopherol compounds in chara sp 


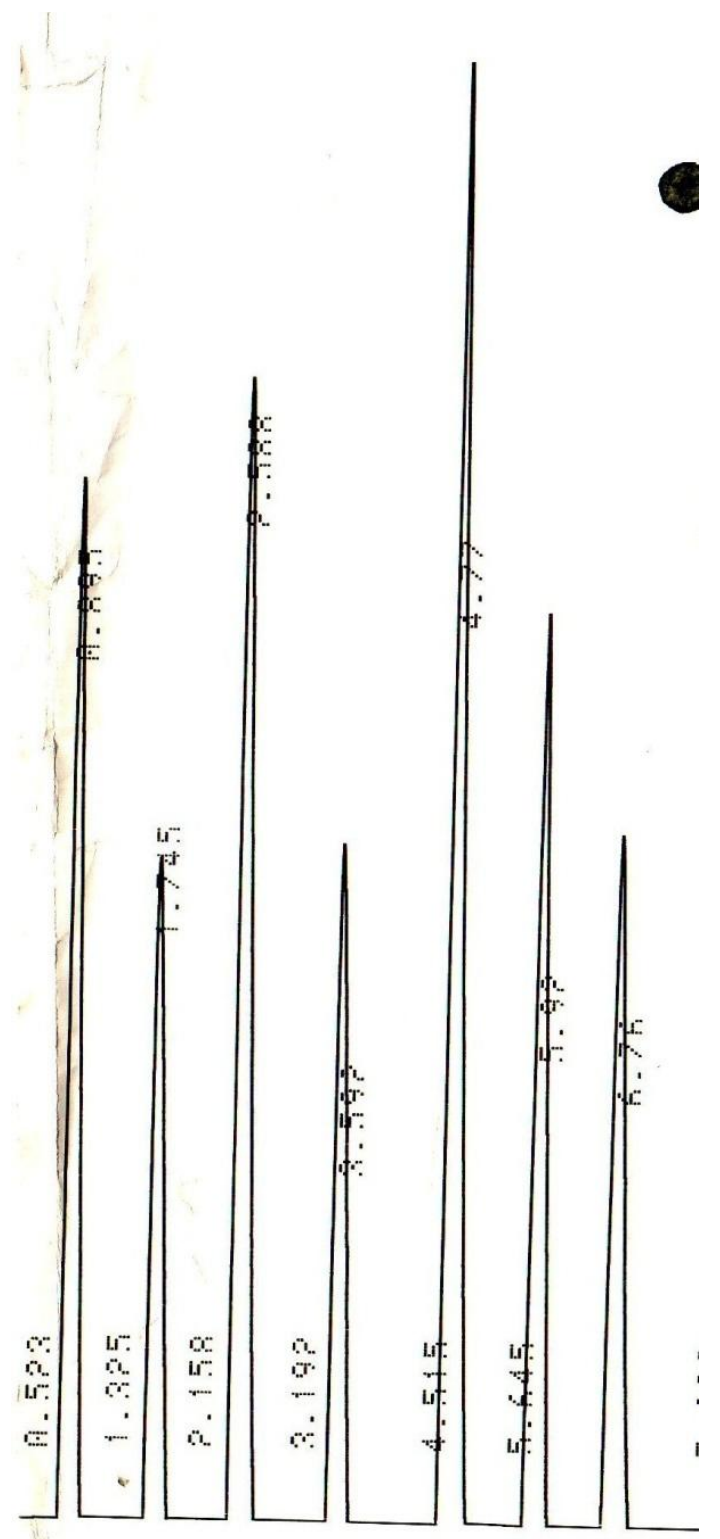

Fig (11): HPLC Chromatogram's of a mixture of authentic standards of tocopherol compounds

\section{Conclusion :}

Different compounds of alkaloid occur in relatively high concentration in two green genus Macro algae that have taken from Bestansur village from sulaimani city Kurdistan region -Iraq.

Different compounds of steroid also occur in relatively high concentration in two genus Macro algae from Bestansur like (stigmasterol ,campesterol , $\beta$ - sitosterol ,avenasterol and clerosterol ).

Physterol occur as organic compounds and essential constituents of cell membranes in all plant oils.

Recently increased interest in phytosterol lies in their potential to reduce plasma.

Different tocopherol occurs in relatively high concentration especially $\alpha$-tocopherol.

And the amount of these elements like $\mathrm{Ca}, \mathrm{Mg}, \mathrm{Cr}, \mathrm{Cd}$,As are exist in these these Macro algae that useful .

This validated method could help to identify the level of numerous toxic and bioactive elements in Macro algae.

\section{Acknowledgement:}

We are very much indebted to the department of chemistry, faculty of science and science education, university of sulaimani for providing the facilities, encouragement and financial support during the investigation .also thanks due to the University of Bagdad for obtaining HPLC technique for identification of the phytosterol compounds and alkaloids and tocopherol in two types of macro algae. 


\section{Reference:}

[1]. S.V. Khotimchenkp ,I.V. Kulikova ,Bot. Mar. 43(2000) 87

[2]. K. Ito, K. Hori , Food Rev. Intern. 5 (1989) 101.

[3]. M.H. Norziah, C.Y. ching ,food chem . 68 (2000) 69

[4]. Kappel meier , P.Die Konstitutions Erforschung der wichtigten opium alkaloid ; verlag von Ferdinanad Enke :Stuttgart, Germany ,1912; p.4.

[5]. Guven , K.C. ; Bora ,A.; Sunam , G. Alkaloid content of Marine algae .I.Hordenine from phyllophera nervosa Eczacihk Bul 1969, $11,177-184$.

[6]. Guven ,K.C. ; Bora ,A.; Sunam ,G. Hordenine from the algae phyllophora nervosa phytochemistry $1970,9,1893$

[7]. Blunt , J.W. ,B.R. Copp ,M.H.G. Munro , P.T. Northcote and M.R. Prinsep ,2006. Marine natural products .Natur. prod. Report ,23:26-78

[8]. Tasende MG. 2000 .Fatty acid and sterol composition of gametophytes and saprophytes of chondrusb Crispus . Scientia Marina 64 (4) , 421-426.

[9]. Dunford NT ,King JW. ,2000 .Phytosterol enrich ment of rice bran oil by a supercritical carbon dioxide Fractionation technique. J. Food science 65, 1395-1399

[10]. J.F. Gregory , in : O.R. Fennema (Ed.), Quimica de los Alimentos , Acribia , 2000 ,p.633 , chapter 8.

[11]. D.M. Czajka - Naris , in : L.K. Mahan, S . Escott-stump (Eds.), Nutrician y Dietoterapia, De Krause, McGraw -Hill, Mexico , 2000 ,p- 77, chapter 6.

[12]. F. Castillo ,J. Cardenas, in : E.Herrera (Ed.) ,Bioquimica, Aspectos Estructurales y vias Metabolieas , Interamericana Mc Graw Hill ,Spain ,1991 ,p.761, chapter 28. 